\title{
Pelatihan Ilmu Informasi Dan Teknologi Komputer Dalam Meningkatkan Kemampuan Administrasi Perangkat Desa Tan Saril
}

\author{
Richasanty Septima $S^{1}$, Ira Zulfa ${ }^{2}$ \\ Fakultas Teknik Universitas Gajah Putih, Belang Bebangka, Takengon Aceh Tengah ${ }^{1,2}$ \\ Email: ira.Zulfea@yahoo.com
}

\begin{abstract}
ABSTRAK
Ilmu informasi teknologi dan komputer adalah salah satu ilmu yang banyak digunakan diberbagai bidang kehidupan, salah satunya adalah penggunaan Ilmu teknologi komputer untuk mempermudah pekerjaan perangkat desa. Akan tetapi bagi seorang perangkat desa, pekerjaan itu tidak lah mudah. Salah satu kendalanya adalah minimnya kemampuan perangkat desa untuk memahami teknologi yang ada, sehingga mereka memerlukan waktu yang lama untuk melaksanakan pekerjaan administrasi. Keadaan yang serupa terdapat pada perangkat desa Tan Saril Kecamatan Bebesen Kabupaten Aceh Tengah. Oleh sebab itu solusi yang ditawarkan dalam kegiatan pengabdian kepada masyarakat (PKM) Adalah mengadakan suatu pelatihan ilmu teknologi terkait pekerjaan administratif. Dalam kegiatan pelatihan ini telah dilakukan sesi pemaparan materi baik secara teori maupun aplikasi pada software. Anggota yang hadir sebanyak 15 orang. Pada akhir kegiatan pelatihan telah dibentuk beberapa kelompok kecil yang terdiri dari 3-4 orang untuk mengerjakaan latihan berupa pembuatan surat dan pembuatan banner. Hasil dari latihan tersebut akan dinilai baik dari sisi output maupun prosesnya. Seperti membuat surat dan membuat banner. Dari segi kriteria output, dinilai berdasarkan pemahaman 4 kelompok, dimana telah terpenuhi dengan kriteria nilai 80\% tuntas. Sedangkan dari segi proses, respon yang diberikan oleh seluruh peserta juga sangat positf. Dengan demikian, dapat disimpulkan bahwa pelatihan telah berhasil dari sisi proses dan output.
\end{abstract}

Kata kunci: ilmu informasi teknologi dan komputer, perangkat desa, mail merge, corel draw

\begin{abstract}
Computer and technology information of science is one of the sciences that is widely used in various fields, one of which is the use of computer technology science to facilitate the work of village officials. But for a village official who sometimes only has a high school education, the work is not easy. One obstacle is the lack of capacity of village officials to understand the existing technology, so they require a long time to carry out administrative work. A similar situation is found in the village of Tan Saril, Bebesen Subdistrict, Central Aceh District. Therefore the solution offered in community service activities (PKM) is to conduct a technology science training related to administrative work. In this training activity, a material exposure session has been conducted both in theory and application in software. There were 15 members present. At the end of the training activity, several small groups of 3-4 people had been formed to work out the exercises in the form of letter writing and banner making. The results of the exercise will be assessed both in terms of output and the process. Like making letters and making banners. In terms of output criteria, assessed based on the understanding of 4 groups, which have been met with a criterion of $80 \%$ value is complete. While in terms of the process, the responses given by all participants were also very positive. Thus, it can be concluded that the training was successful in terms of process and output.
\end{abstract}

Keywords: technology information, village apparatus, mail merge, Corel draw 


\section{PENDAHULUAN}

Pemerintahan desa merupakan unit terkecil pada struktur pemerintahan daerah, pemerintahan desa memiliki tugas dan kewenangan tersendiri sebagaimana diatur dalam undang-undang no. 6 tahun 2014 Tentang desa .Untuk dapat melaksanakan tugas menyelenggarakan pemerintahan desa, ditiap-tiap pemerintahan desa di lengkapi dengan sarana dan prasarana pendukung diantaranya ialah kelengkapan struktur organisasi yang didalamnya terdapat perangkat pemerintahan desa dengan tugas dan fungsi yang melekat di tiap struktur organisasi yang ada.

Perangkat desa adalah salah satu yang memegang peranan penting dalam perkembangan pemerintahan tingkat desa. Sebagai perangkat desa yang berusaha untuk meningkatkan kualitas dalam memberikan pelayanan kepada masyarakat, tentunya perangkat desa itu sendiri harus memiliki kemampuan yang baik dalam bidang teknologi sehingga dapat memberikan pelayanan yang terbaik kepada masyarakat. Oleh karena itu, sebagai seorang perangkat desa diharapkan untuk selalu meningkatkan profesionalismenya, salah satu hal yang bisa dilakukan adalah dengan dengan mengikuti pelatihan-pelatihan ilmu informasi teknologi dan komputer terkait kegiatan administrasi desa.

Akan tetapi, sedikit sekali Lembaga Swadaya Masyarakat (LSM) atau badan-badan yang melakukan pelatihan di bidang IT apalagi untuk daerah-daerah pedesaan yang belum berkembang. Dan dalam kenyataannya, banyak juga perangkat desa yang belum mau mengikuti pelatihan-pelatihan ilmu teknologi baik didalam maupun diluar desanya. Mereka tidak memahami pentingnya mengikuti pelatihan ilmu teknologi untuk meningkatkan kemampuan administrasi perangkat desa, terutama dibidang surat menyurat dan pembuatan banner. Sering ditemui, untuk pengerjaan pembuatan banner perangkat desa hanya mengandalkan rental desain sehingga mengeluarkan banyak waktu dan biaya.

Penguasaan ilmu bidang informasi dan teknologi (IT) merupakan sebuah kebutuhan dalam menghadapi era globalisasi. Menurut Purwanto (2017) kemajuan teknologi sesuatu yang tidak bisa kita hindari dalam kehidupan ini, karena kemajuan teknologi akan berjalan sesuai dengan kemajuan ilmu pengetahuan. Tidak kurangnya dalam bidang pemerintahan. Teknologi informasi berbasis computer mampu meningkatkan efisiensi dan efektifitas kinerja. Secara praktis, ini terjadi apabila sistem dirancang dengan sempurna bagi semua user yang memiliki pemahaman pengertian manajerial dan organisasi (Kasemin, 2016). Pembuatan surat, banner atau dokumen lainnya yang dulunya menggunakan mesin ketik atau melalui bantuan rental desain, sekarang menggunakan komputer yang lebih praktis dan efisien karena bisa kita pelajari sendiri dan mempraktekkan langsung pada pekerjaan sebagai perangkat desa. Adapun pembuatan surat yang baik dapat menggunakan aplikasi Mail Merge sedangkan untuk pembuatan banner dapat menggunakan aplikasi Corel Draw.

Mail merge adalah salah satu software yang dapat digunakan untuk mempermudah para pengguna untuk membantu membuat sebuah dokumen (misalnya surat) yang isinya sama untuk penerima yang berbeda secara cepat dan mudah. Fitur ini sangat membantu terutama bila penerimanya santa banyak. Mail merge juga dapat digunakan untuk membuat sertifikat, label dan amplop. Sedangkan corel draw merupakan sebuah program komputer editor grafik 
vektor yang berfungsi untuk mengolah gambar dan banyak digunakan pada bidang publikasi, percetakan, dan bidang lain yang membutuhkan proses visualisasi. Dilihat dari fungsinya dua aplikasi mail merge dan corel draw adalah aplikasi yang sangat penting dalam penggunaannya pada perangkat desa guna meningkatkan pelayanan administrasi desa, selain mempermudah dan mempercepat pekerjaan juga salah satunya adalah menghemat biaya.

Mitra yang bekerjasama pada program pengabdian masyarakat ini adalah perangkat desa pada desa Tan Saril Kecamatan Bebesen Kabupaten Aceh Tengah. Dari pengamatan dilapangan dan wawancara yang dilakukan oleh tim dengan perangkat desa Tan Saril, diketahui bahwa sebagian perangkat desa ada yang sudah memahami ilmu informasi teknologi dan komputer, misalnya untuk aplikasi Microsoft Word tetapi masih banyak perangkat desa yang belum memahami pentingnya penggunaan mail merge dan corel draw dalam membantu mempermudah pekerjaan mereka.

Berdasarkan latar belakang tersebut dan khususnya rasa keinginan belajar yang sangat besar dari para perangkat desa , maka sebagai upaya pengabdian kepada masyarakat untuk membekali soft skill perangkat desa kami dari tim pelaksana pengabdian kepada masyrakat jurusan Teknik Informatika Fakultas Teknik Universitas Gajah Putih akan mengadakan pelatihan berupa Pelatihan Ilmu Informasi Teknologi dan Komputer khususnya aplikasi Mail Merge dan Corel Draw, karena melalui pelatihan akan diperoleh pengetahuan dan keterampilan yang dibutuhkan untuk pekerjaan sehingga dapat didayagunakan secara optimal melalui terciptanya suatu kondisi tenaga kerja yang memenuhi semboyan The Right Man On The Right Job At The Right Time yaitu tepat orang, tepat pekerjaan dan tepat waktu yang semuanya dapat mendukung manajemen kinerja organisasi (Niati, 2019).

Adapun tujuan dari kegiatan program pengabdian masyarakat ini adalah meningkatkan kemampuan administrasi perangkat desa Tan Saril dalam bidang ilmu informasi teknologi dan komputer, sehingga tercipta perangkat desa yang siap kerja dan mampu bersaing dalam segala bidang.

\section{METODE}

Berdasarkan uraian sebelumnya, maka solusi yang ditawarkan adalah melakukan pelatihan ilmu informasi teknologi dan komputer untuk memahami cara membuat surat dan membuat banner dengan aplikasi komputer mail merge dan corel draw. Peserta kegiatan ini adalah perangkat desa pada desa Tan Saril Kecamatan Bebesen Kabupaten Aceh Tengah yang berjumlah 15 orang. Kegiatan pelatihan ini dilakukan hanya 1 hari mulai pukul 09.0012.00 Wib, bertempat di Kantor desa Tan Saril.

Sesuai dengan tujuan pelatihan ini yaitu untuk mempermudah dan meningkatkan kemampuan administrasi perangkat desa maka akan digunakan beberapa metode untuk mencapai tujuan tersebut, yaitu:

1. Kegiatan pertama adalah sosialisasi / pemaparan materi tentang pentingnya ilmu informasi teknologi dan komputer dalam berbagai bidang aspek kehidupan.

2. Kegiatan kedua adalah pemaparan materi tentang konsep mail merge dalam proses pembuatan surat dan corel draw dalam proses pembuatan banner. 
3. Kegiatan ketiga adalah pelatihan pembuatan surat dan pembuatan banner dengan menggunakan software.

4. Kegiatan Keempat adalah membentuk 3-4 kelompok kecil untuk melakukan latihan berdasarkan teori dan praktek yang telah diberikan untuk menguji pemahaman anggota pelatihan dalam menghasilkan surat dan banner yang baik.

Sedangkan untuk penilaian dilakukan dalam dua tahap, yaitu persiapan dan pelaksanaan pelatihan, yaitu:

1. Pada tahapan persiapan, penilaian dilakukan terhadap kesiapan handout untuk peserta, bahan presentasi serta tersedianya sarana dan prasarana. Jika telah tersedia sesuai dengan yang direncanakan, maka persiapan dikatan baik atau memenuhi kelayakan. Selanjutnya yaitu tahap pelaksanaan.

2. Pada tahapan pelaksanaan hal-hal yang akan dinilai adalah kriteria keberhasilan dari sisi output dan proses. Pada kriteria ouput kegiatan dikatakan berhasil jika paling sedikit $80 \%$ untuk setiap kelompok dan seluruh kelompok mampu membuat surat dan banner menggunakan software mail marge dan corel draw dan memberikan kesimpulan yang baik. Sedangkan pada kriteria proses, kegiatan dikatakan berhasil apabila peserta memberikan respon yang positif, antusias, semangat, dan menyatakan untuk melanjutkan kegiatan pelatihan yang serupa dengan materi yang berbeda untuk lebih meningkatkan kemampuan perangkat desa tersebut.

\section{HASIL, PEMBAHASAN, DAN DAMPAK}

Kegiatan pengabdian kepada masyarakat (PKM) dilaksanakan pada hari Selasa, 04 September 2018 dari mulai pukul 09.00-12.00 Wib, bertempat di Kantor Desa Tan Saril Kecamatan Bebesen Kabupaten Aceh Tengah dengan peserta yang terdiri dari perangkat desa yang berjumlah 15 orang. Kegiatan pelatihan ini diisi oleh 2 Pemateri dari dosen teknik informatika yaitu Richasanty Septima S, S.Si, M.Mat untuk materi mail marge dan Ira Zulfa, M.Cs untuk materi desain banner dengan menggunakan corel draw. Pelatihan dilakukan secara langsung antara materi dan praktek, hal ini bertujuan agar peserta lebih memahami dan memiliki pengalaman secara langsung dari materi yang disampaikan.

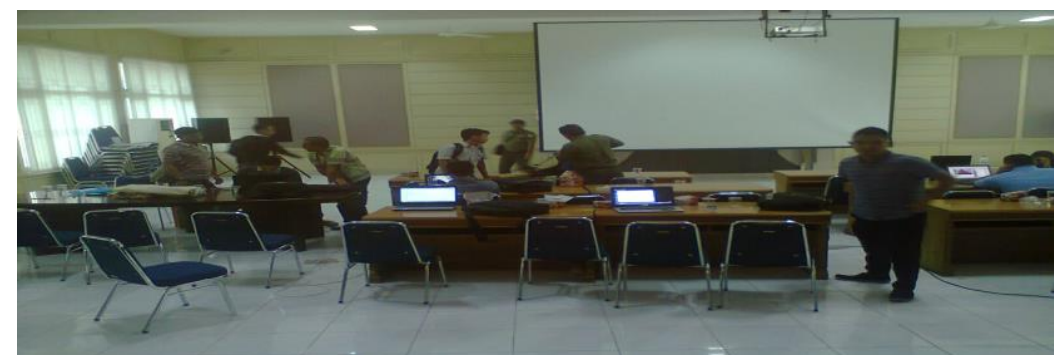

Gambar 1. Kegiatan awal sebelum pelatihan dimulai.

Kegiatan pelatihan ini dilakukan hanya satu sesi mengingat jumlah peserta yang tidak terlalu banyak. Pada kegiatan pertama pelatihan dibuka oleh salah satu anggota PKM dan langsung diteruskan dengan pemaparan tentang pentingnya mempelajari ilmu informasi teknologi dan komputer untuk meningkatkan kemampuan administrasi desa, dilanjutkan 
dengan pemaparan oleh pemateri pertama tentang mail marge. Pemaparan materi selanjutnya dilakukan oleh pemateri kedua dengan materi desain banner. Selama proses pemaparan materi tersebut, kegiatan ini didukung oleh dua mahasiswa dari jurusan Teknik informatika, mereka bertugas menginstal software mail marge dan corel draw yang akan didemonstrasikan selama proses pelatihan.

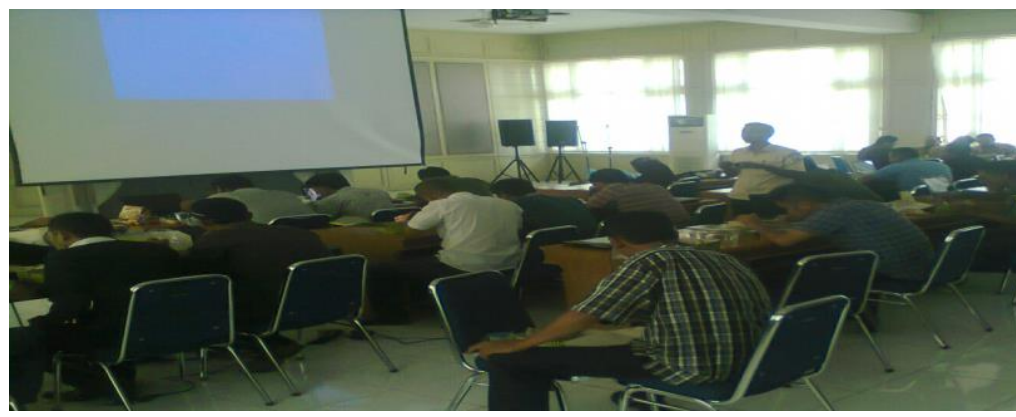

Gambar '2. Kegiatan Ketıga, Pelatıhan sudah dimula1.

Pada saat akhir pelatihan dibentuk 4 kelompok yang terdiri dari 3-4 orang. Kemudian penyaji memberikan beberapa pilihan surat dan banner yang harus dikerjakan oleh masingmasing kelompok. Sedangkan pada sesi evaluasi diberikan waktu sekitar 1 jam kepada 4 kelompok untuk menyelesaikan secara komprehensif kasus yang disajikan oleh penyaji.

Hasil evaluasi dari pelaksanaan kegiatan pelatihan ilmu teknologi ini adalah bahwa kegiatan ini telah mencapai kriteria keberhasilan yang telah ditetapkan. Hal yang pertama adalah ketuntasan keberhasilan dari penyelesaian problem secara komprehensif dengan meggunakan aplikasi mail marge dan corel draw untuk desain banner telah diatas $80 \%$. Hal itu berdasarkan fakta bahwa hanya $20 \%$ yang mendapatkan nilai 80 dari 100 dan sisanya mendapatkan nilai sempurna. Faktor yang kedua adalah ketuntasan pemahaman materi oleh setiap kelompok telah mencapai target yaitu diatas $80 \%$ ketuntasan. Hal ini dikarenakan 3 dari 4 kelompok mendapatkan nilai sempurna (100) dan hanya 1 kelompok yang melakukan kesalahan dalam proses penggabungan surat pada mail marge sehingga memperoleh nilai 80 dari 100. Berdasarkan hasil evaluasi tersebut memperkuat fakta bahwa pelatihan ini berhasil mencapai keberhasilan seperti yang diharapkan.

Untuk kriteria yang kedua adalah adanya respon yang positif selama pelatihan. Selama pelatihan respon yang didapatkan sangatlah positif antara lain pelatihan yang dilakukan sangat baik, menarik, cara penyajian sangat bagus, para penyaji juga sangat sabar dalam memberikan materi terutama saat sesi praktek. Sedangkan saran-saran yang diperoleh dari penyebaran angket kepada perangkat desa, dapat disimpulkan bahwa para perangkat desa menginginkan ada kelanjutan untuk pelatihan dengan materi teknologi komputer lainnya, untuk lebih mengembangkan kemampuan administrasi perangkat desa Tan Saril.

\section{SIMPULAN}


Dari uraian diatas, dapat disimpulkan bahwa pelatihan ilmu teknologi komputer untuk meningkatkan kemampuan administrasi perangkat desa Tan Saril sangatlah dibutuhkan, namun terdapat kendala yaitu tidak adanya software yang mendukung pekerjaan yang dibutuhkan oleh perangkat desa. Sehingga dengan melakukan pelatihan ilmu teknologi komputer berupa software mail marge dan corel draw untuk desain banner ini mampu menjadi salah satu alternatif untuk menambah wawasan dan ilmu bahwa ada banyak kemudahan dalam ilmu teknologi komputer dalam proses penyedia layanan untuk masyarakat desa, dimana dapat menghemat waktu dan biaya baik bagi penyedia layanan maupun bagi penerima layanan. Dalam pelatihan tersebut juga telah mencapai target keberhasilan dari kriteria output dan proses dari peserta pelatihan. Sedangkan pelatihan ilmu teknologi lanjutan yang diingin kan para peserta pelatihan perlu ditindaklanjuti untuk memenuhi pencapaian peningkatan kualitas kemampuan administrasi perangkat desa agar dapat bersaing dengan perangkat desa lainnya serta mampu menciptakan sistem pelayan publik yang baik.

\section{UCAPAN TERIMAKASIH}

Tim Pengabdian kepada Masyarakat (PKM) mengucapkan terima kasih kepada Fakultas Teknik Universitas Gajah Putih yang telah mendukung pelaksanaan kegiatan PKM serta tidak lupa ucapan terima kasih kepada bapak Tamar Jaya selaku reje kampong Desa Tan Saril, yang telah memberikan ruang dan waktu demi terlaksananya pelatihan tersebut. Dan tak lupa pula terima kasih kami ucapkan kepada para peserta yaitu para perangkat desa Tan saril yang telah memberikan kesempatan rasa antusias yang baik kepada para panitia pelaksana Pelatihan Ilmu Informasi Teknologi dan Komputer ini sehingga pelatihan ini dapat berjalan dengan baik, aman dan lancar.

\section{DAFTAR PUSTAKA}

A`yunin Sofro., Affiati Oktaviarina., Dwi Juniati dan I Ketut Budayasa. (2019). Jurnal Pengabdian Masyarakat MIPA dan Pendidikan MIPA: Pelatihan Analisis Statistik untuk Karya Tulis Ilmiah Bagi Guru-guru SMA Kediri,3(1), 38-42.

Ardoni, (2006). Jurnal Studi Perpustakaan dan Informasi: Teknologi Informasi, 1(2).

Irmayani., Andi Manguntungi Sudirman. (2019). Abdimas Toddopuli: Jurnal Pengabdian Masyarakat: Pengembangan Sumber Daya Manusia Melalui Pelatihan Microsoft Office Pada Aparat Desa di Kecamatan Lamasi Kabupaten Luwu Provinsi Sulawesi Selatan,1(1), 20-27

Kasemin, K. (2016). Agresi Perkembangan Teknologi Informasi. Jakarta: Pramedia Group.

Kurniawan, Agung. (2005). Transformasi pelayanan Publik. Jakarta: Penerbit Pembaruan.

Niati, A., Soelistiyono, A., \& Ariefiantoro, T.(2019). E-Dimas: Jurnal Pengabdian Masyarakat: Pengembangan Kemampuan Sumber Daya Manusia melalui Pelatihan Komputer Microsoft Office Excel untuk Meningkatkan Kinerja Perangkat Desa Mranggen .10(01), 105-110. 
Purwanto, Y., Taufik, M., \& Jatnika, A.W. (2017). Peran Teknologi Informasi dalam Perkembangan Dakwah Manusia. Jurnal Sosioteknologi, 16(1), 94-109.

Undang-undang Nomor 6 Tahun 2014 Tentang Desa. 